\title{
Community structure of macroinvertebrates inhabiting the rocky subtidal zone in the Gulf of Maine: seasonal and bathymetric distribution*
}

\author{
F. Patricio Ojeda**, John H. Dearborn \\ Department of Zoology, University of Maine, Orono, Maine 04469, USA
}

\begin{abstract}
Community structure of the macroinvertebrate fauna inhabiting a rocky subtidal habitat at Pemaquid Point, Maine, USA, was studied, using qualitative and quantitative descriptions of the distribution, diversity and abundance of benthic species, as well as their spatial (bathymetric) and temporal (seasonal) changes. A total of 60 species of macroinvertebrates representing 9 phyla were found in the $133\left(0.25 \mathrm{~m}^{2}\right)$ disruptive benthic samplings obtained by SCUBA between August 1984 and October 1986. Crustaceans, mollusks and polychaetes were best represented accounting for ca $77 \%$ of the total number of species identified. Green sea urchin Strongylocentrotus droebachiensis and horse mussel Modiolus modiolus were consistently the most important (in biomass and density) assemblage components. Bathymetrically, there were clear patterns in the composition and abundance of macroinvertebrates. Sea urchins decreased in abundance with depth (from 5 to $18 \mathrm{~m}$ ), while the opposite was observed in horse mussels. Distribution and abundance patterns of remaining benthic macroinvertebrates were strongly influenced by the spatial distributions of sea urchins (at 5 and $10 \mathrm{~m}$ depth) and horse mussels (at $18 \mathrm{~m}$ ). Species richness was higher in the deepest zone (18 $\mathrm{m} ; 41$ species) than in the shallower zones ( 5 and $10 \mathrm{~m} ; 34$ and 31 species respectively), due to the presence of clumps of $M$. modiolus. Comparative analysis at $18 \mathrm{~m}$ depth showed that the invertebrate fauna within Modiolus beds is significantly more abundant, dense, and diverse than that outside pointing out the functional importance of Modiolus beds in providing spatial refuges from predators, and suitable and stable microhabitats for numerous invertebrates. No significant temporal changes were observed in the biomass and density of the invertebrate community. Number of species, however, showed marked seasonal variations. Maximum values occurred during summer, intermediate values in fall and spring, and minimum values in winter, probably related to migration or changes in activity of some species. Results of this and other studies indicate that coralline communities, despite their low primary productivity, are ecological systems with relatively high species diversity and secondary productivity, sometimes comparable to systems dominated by kelps.
\end{abstract}

\section{INTRODUCTION}

Kelp forests and systems dominated by encrusting organisms and sea urchins are probably the most conspicuous and prevalent communities of rocky subtidal habitats of most temperate coasts (Mann 1972, Miller \& Mann 1973, Steneck 1978, 1986, Duggins 1980, Ayling 1981, Choat \& Schield 1982, Moreno \& Sutherland

\footnotetext{
- Contribution of the Department of Zoology, Migratory Fish Research Institute and Ira C. Darling Center of the University of Maine

- Present address: Departamento de Ecologia, Facultad de Ciencias Biologicas, Pontificia Universidad Catolica de Chile, Casilla 114-D, Santiago, Chile
}

1982, Hagen 1983, Logan et al. 1984, Santelices \& Ojeda 1984, Dayton 1985a, b, Sebens 1985, 1986a, b, Johnson \& Mann 1986a). Characteristically, kelp forest communities are highly productive and structurally complex. Because of the ecological and economic importance of kelp species, communities dominated by these large brown algae have been studied extensively throughout the world (e.g. reviews by North 1971, Dayton 1985).

In contrast, communities dominated by encrusting organisms such as crustose coralline algae and large herbivores such as sea urchins have low productivity and species diversity, and in general have received relatively little attention.

Crustose coralline communities (or 'barren grounds' 
sensu Lawrence 1975) have recently stimulated considerable research particularly on ecological mechanisms responsible for their origin and maintenance. Basically, kelp forest and crustose coralline communities have been shown to represent alternative states (Mann 1977 Harrold \& Reed 1985, Scheibling 1986). The transition from one state to the other is usually attributed to changes in the abundance of sea urchins. At high densities, urchins are known to deplete the marine flora (mostly kelp), producing large 'barren' patches dominated by crustose red algae. The nearshore ecosystem along coastal Atlantic Canada (Nova Scotia) has recently experienced this kind of dramatic change of state. Destructive overgrazing by sea urchins transformed kelp forests into crustose coralline communities in the mid 1960's, and the more recent (in the 1980's) mass mortalities of sea urchins have caused the recovery of kelp (Mann 1977, Pringle et al. 1980, Wharton \& Mann 1981, Miller 1985, Scheibling 1986; see Pringle 1986 for review).

Rocky subtidal habitats of the New England (USA) coast are dominated largely by crustose coralline communities (Steneck 1986), dense populations of green sea urchins Strongylocentrotus droebachiensis and a diverse fauna both of sessile and mobile forms (Steneck 1978, 1986, Larson et al. 1980, Logan et al. 1983, 1984, Sebens 1985, 1986a, Witman 1985). In these environments, kelp species (mainly Laminaria and Alaria) and other macroalgal associations are in general less common, usually occupying a narrow zone in shallow waters, or a more extensive band in some protected habitats where urchins are absent or rare (Sebens 1985 , $1986 a$; pers. obs.). Vertical rocky surfaces of these subtidal habitats support diverse assemblages of organisms, usually dominated by a suite of encrusting invertebrate species (Sebens 1986a, b).

The distributional patterns and other relevant aspects of the ecology of crustose coralline algal species inhabiting subtidal rocks of the Gulf of Maine have recently been documented by Steneck (1978, 1982) and Garwood et al. (1985). Similarly, the structure and organization of several encrusting invertebrate communties occurring in the sublittoral zone of the New England coast have been examined by Osman (1977) and Sebens (1982, 1986a, b). Other important aspects related to the community organization of these subtidal systems have recently been reported by Witman (1985) and Harris (1986).

Studies describing invertebrate macrofauna inhabiting crustose coralline communities in the Gulf of Maine are also limited. Although Logan et al. (1983) have recently described spatial patterns of distribution of the species comprising coralline-dominated communities of the Bay of Fundy (New Brunswick, Canada), other important autecological aspects of some of the most conspicuous macroinvertebrates as well as temporal changes in the structure of such communities remain unknown.

This study describes the community structure of macroinvertebrates inhabiting a crustose coralline community in a rocky subtidal habitat off the coast of Maine. This characterization involves qualitative and quantitative descriptions of the distribution, diversity and abundance of benthic macrofauna as well as their spatial (bathymetric) and temporal (seasonal) changes. Large mobile predators (such as decapod crustaceans and fish of large size) are excluded in this study as well as the epibenthic invertebrate fauna typical of vertical walls. The large mobile fauna associated with this community is discussed separately elsewhere (Ojeda \& Dearborn unpubl.). As noted previously, the invertebrate assemblages inhabiting vertical and undercut. rocky surfaces have been analyzed extensively by Sebens (1982, 1986a, b; and papers cited therein).

The ecological patterns described in this study have important implications since they provide a base line for future research and the required ecological background toward our understanding of the organization and the dynamic processes operating in this kind of community.

\section{DESCRIPTION OF STUDY SITE}

This study was conducted in the shallow subtidal zone off the southwest end of Pemaquid Point, Maine, USA $\left(43^{\circ} 50^{\prime} \mathrm{N}_{;} 69^{\circ} 31^{\prime} \mathrm{W}\right.$ ) (Fig. 1). The site is exposed to the prevailing southeast ocean swells and consists of a sloping bedrock surface extending down to ca 18 to $20 \mathrm{~m}$ depth (Fig. 2). The shallower portion of this bedrock (between 12 and $15 \mathrm{~m}$ depth) consists of a broad ledge. The substrate here is relatively flat, almost free of silt and cobble, and occasionally cut by crevices and small cracks. Large rocks and boulders are commonly found on shelves of bedrock at depths of 15 to $20 \mathrm{~m}$. The substrate at depths greater than $20 \mathrm{~m}$ consists primarily of sand with occasional round boulders (Fig. 2)

The zonation pattern of species found in the study area is quite uniform and representative of waveexposed habitats of the New England coasts. The shallowest subtidal zone $(0$ to $5 \mathrm{~m}$ below Mean Low Water Level; MLWL) at this site is clearly dominated by macroalgal species. Extending from the low intertidal zone to the uppermost sublittoral zone there is a conspicuous belt of Chondrus crispus. A narrow band of kelp species (primarily Laminaria saccharina, L. digitata, and Alaria esculental occurs immediately below the Chondrus zone. Most of these kelps, however, are juveniles (less than $1 \mathrm{~m}$ long) with few adult individuals 


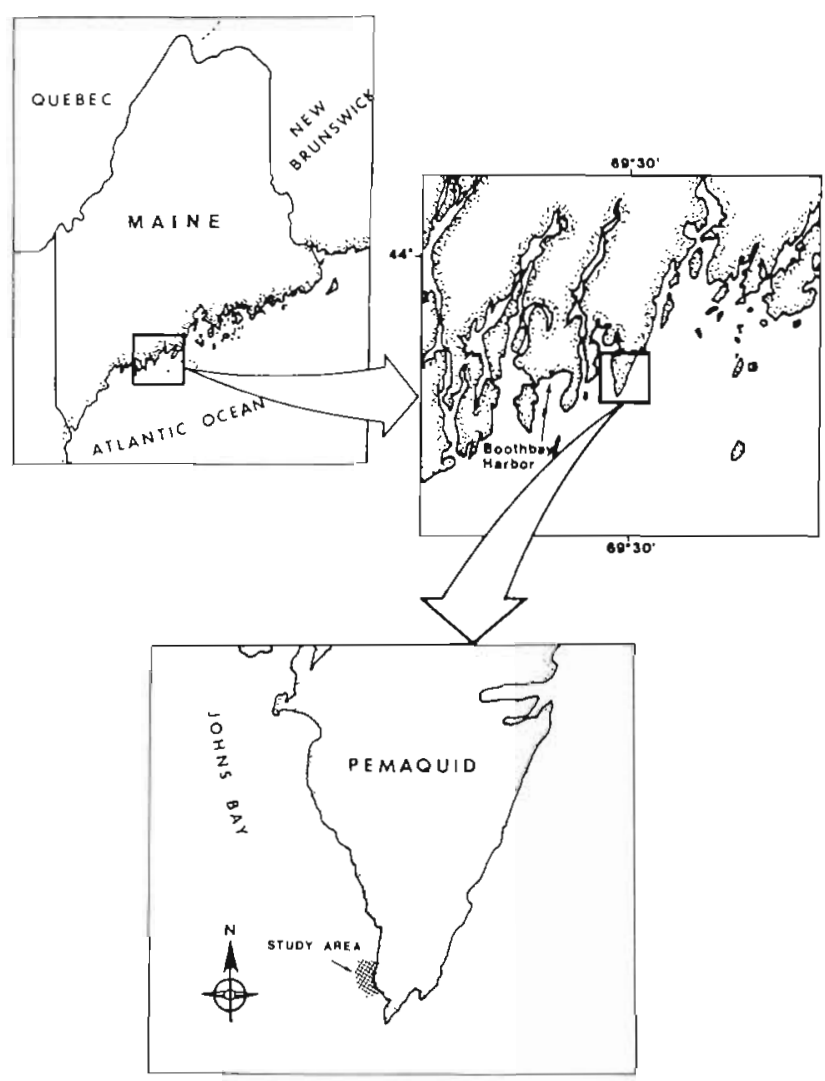

Fig 1. Maine, USA, showing location of study site

reaching sizes larger than $2 \mathrm{~m}$. The understory of the kelp zone is mostly composed of dense tufts of Corallina officinalis, and small patches of Phycodrys rubens, Phyllophora sp., and Ceramium rubrum. The deeper border of the macroalgal zone is occupied by a diverse algal turf primarily consisting of elongated individuals of Enteromorpha spp. Ulva spp. Chordaria flagelliformis, Polysiphonia spp., Chaetomorpha melagonium and C. linium (Fig. 2).

Most of the primary substratum (ca 70 to $80 \%$ ) across the rock ledge (between 4 and $15 \mathrm{~m}$ depth) is covered by crustose coralline algae which form a nearly continuous pink carpet. A similar situation is observed on the top surfaces of the rocks and boulders found in the deeper zone (between 15 and $20 \mathrm{~m}$ depth). The shallow portion of the coralline zone (between 4 and $15 \mathrm{~m}$ ) is dominated by the corallines Lithothamnium glaciale, L. lemoineae, Clathromorphum circumscriptum, and Phymatoliton rugulosum. The top surfaces of the large boulders and rocks of this zone (between 16 to $20 \mathrm{~m}$ ) are mostly dominated by Lepthophytum laeve and Phymatolithon laevigatum. A detailed description of the crustose coralline assemblages inhabiting this locality was given by Steneck (1978).

The most conspicuous organism inhabiting horizontal and sloping rock surfaces of the coralline zone is the green sea urchin Strongylocentrotus droebachiensis, which forms dense aggregations extending from 3 to $12 \mathrm{~m}$ deep. At this location green urchins occur to depths of 20 to $25 \mathrm{~m}$, however, their abundance declines sharply below $15 \mathrm{~m}$ (Fig. 2). Patchily distributed clumps of the horse mussel Modiolus modiolus occur at depths of 10 to $20 \mathrm{~m}$. Their large shells are usually covered with encrusting coralline algae, barnacles, and small tunicates. The interstices between the mussels and the weft of byssus threads create a suitable habitat and shelter for numerous invertebrate organisms. At the deeper edge of the rocky boulder field (ca 17 to 20 $\mathrm{m}$ ) isolated individuals of Agarum cribosum are usually found attached to top surfaces of large rocks and boulders (Fig. 2).

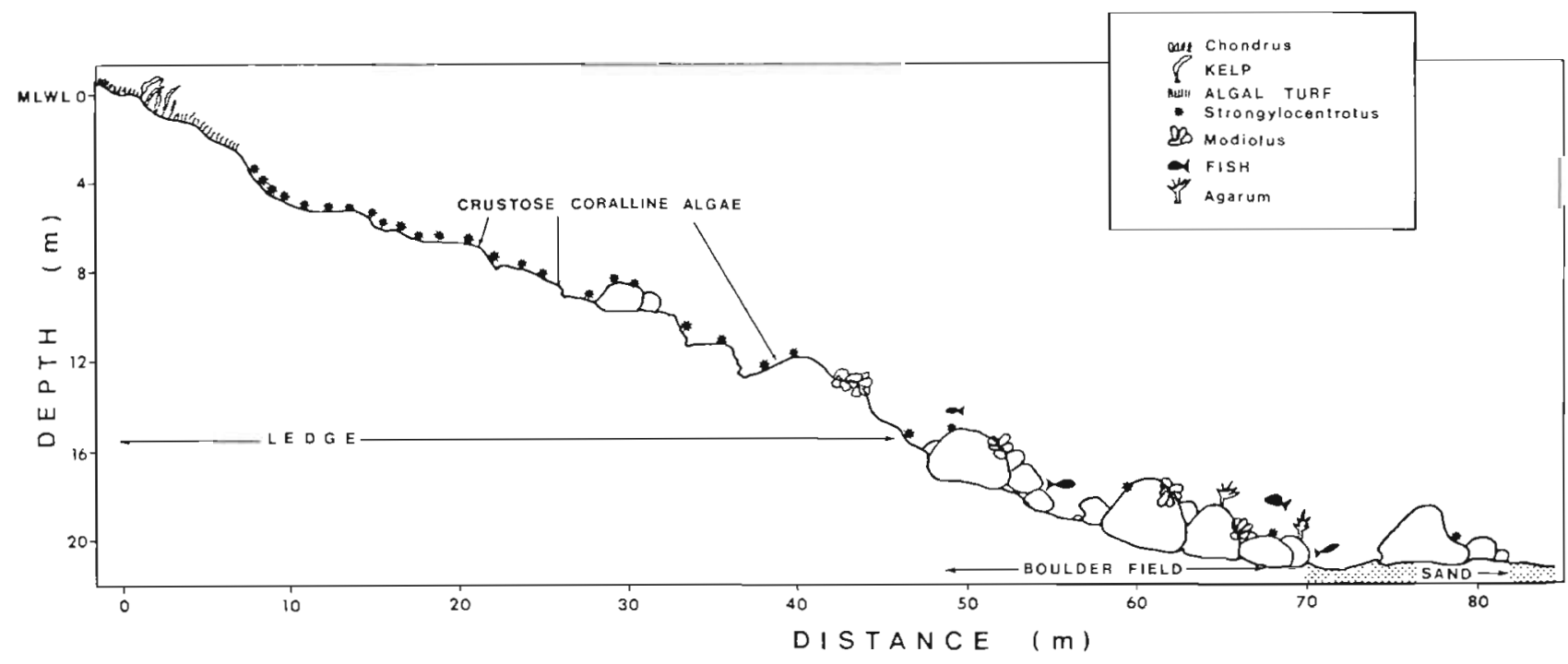

Fig 2. Transectional view of a typical subtidal coralline community at Pemaquid Point, Maine 


\section{MATERIALS AND METHODS}

Nine disruptive samplings were conducted seasonally using SCUBA from August 1984 to October 1986. In each of the seasonal samplings several transects were carried out perpendicular to the shore. Four to 8 quadrat samples $\left(0.25 \mathrm{~m}^{2}\right.$ ) (Pringle 1984) were randomly taken from 3 different depth ranges ( 4 to $6 \mathrm{~m}, 9$ to $11 \mathrm{~m}$, and 16 to $20 \mathrm{~m}$; hereafter designated 5, 10 and $18 \mathrm{~m}$ respectively) according to a stratified random sampling design (Elliott 1977). All macroinvertebrates found within the quadrat were removed from the substrate with the aid of scraping knives and forceps. The organisms then were either manually collected and deposited in diver sampling bags of 1 to $2 \mathrm{~mm}$ mesh size or vacuumed with an airlift device (Chess 1978 , Witman 1985). All sampled organisms of each quadrat were placed in labelled plastic bags, fixed in a 5 to $10 \%$ solution of buffered (borax) formalin-seawater mixture, and transported to the laboratory for analysis.

In the laboratory, the organisms were sorted, identified to the lowest taxon possible, usually to species, counted, measured with a caliper to the nearest $0.1 \mathrm{~mm}$ and weighed on a Mettler P1200 balance to the nearest $0.1 \mathrm{mg}$.

In order to establish spatial patterns of species associations, a cluster analysis based on Ward's method which uses Euclidean distance as a metric (CLUSTER Procedure; SAS 1986) was performed using mean density values at 3 depths $(5,10$ and $18 \mathrm{~m})$ of the 24 most abundant macroinvertebrate taxa found in the samples. The data on macroinvertebrate densities and biomasses were tested for homogeneity of variances using the $F_{\max }$ test (Sokal \& Rohlf 1981). The results of this test on densities and biomasses showed that the variances were nonhomogeneous over the bathymetric and temporal gradients studied. Therefore a logarithmic transformation $(\log [n+1]$; Sokal \& Rohlf 1981, p. 419) was used on all these data before further analysis. One-way ANOVA followed by a Student-NewmanKeuls (SNK) multiple comparison test (Sokal \& Rohlf 1981) were employed for the detection of changes in density and biomass of macroinvertebrates over bathymetric and temporal gradients.

\section{RESULTS}

\section{Community structure}

A total of 60 species of macroinvertebrates representing 9 phyla were found in the $133\left(0.25 \mathrm{~m}^{2}\right)$ benthic samples collected from August 1984 to October 1986 (Table 1). Crustaceans, mollusks and polychaetes are the best-represented taxonomic groups with 18, 14, and 14 species respectively. They account for about $77 \%$ of the total number of species recognized in these samples (Table 1).

The green sea urchin Strongylocentrotus droebachiensis is numerically the most important macroinvertebrate in this community with average density of 100 ind. $\mathrm{m}^{-2}$, and accounting for about $56 \%$ of the total number of individuals collected in the benthic samples (Table 2). Modiolus modiolus, Tonicella ruber, and Ophiopholis aculeata are the next species in the ranking of abundances, with density values of ca 9 to 13 ind. $\mathrm{m}^{-2}$ (Table 2). The remaining 56 species $193 \%$ of the total number of species) contribute together only $23.8 \%$ of the total number of individuals collected. Few of these 56 species however, are represented with more than 1 ind. $\mathrm{m}^{-2}$ (Table 2).

Strongylocentrotus droebachiensis is the dominant species in biomass in the samples with an average biomass of $2699 \mathrm{~g} \mathrm{~m}^{-2}$, representing $65.5 \%$ of the total biomass (Table 2). It is followed by Modiolus modiolus, with average biomass of $1303 \mathrm{~g} \mathrm{~m}^{-2}(30.9 \%$ of the total biomass). These 2 species together account for about $95 \%$ of the total biomass of macroinvertebrates (Table 2). Most of the remaining 58 species are represented with less than $10 \mathrm{~g} \mathrm{~m}^{-2}$, contributing relatively little to the overall biomass in this community (usually less than $1 \%$; Table 2 ).

\section{Spatial patterns}

The bathymetric range of distribution of all macroinvertebrate species found in the samples is also presented in Table 1. Fifteen species (25.4\% of the total) restrict their bathymetric distribution exclusively to the shallowest subtidal zone sampled $(5 \mathrm{~m})$. Most of these species were gastropod mollusks (e.g. Lacuna vincta and Littorina littorea), and small crustaceans such as amphipods and isopods (Table 1). Most of the species of this group were found associated with the macroalgal turf typical of this sublittoral zone (Fig. 2). Two other species (3.4\% of the total) were exclusively found at depths of 5 and $10 \mathrm{~m}$, while a group of 17 species (28.8\% of the total) was widely distributed along the bathymetric gradients analyzed (Table 1). The most abundant species of this community (e.g. sea urchins, mussels, chitons, brittle stars; see Table 2 ) belong to this group (Table 1). Two other groups of species were found to be restricted to the deepest zone: one composed of 9 species $(15.2 \%$ of the total) which occur at depths of 10 and $18 \mathrm{~m}$ and, another group of 13 species $(22.4 \%)$ found only in the $18 \mathrm{~m}$ samples (Table 1). Most of the species of this latter group were closely associated with the Modiolus clumps.

The total number of species (species richness) was markedly higher in the samples taken at $18 \mathrm{~m}$ depth 
(41 species, $69.5 \%$ of the total) and lower at the intermediate depth of $10 \mathrm{~m}$ ( 31 species, $52.5 \%$ of the total). The samples taken at $5 \mathrm{~m}$ depth contained a few more species than those found at $10 \mathrm{~m}$ depth (34 species, $57.6 \%$ )

An analysis of the bathymetric variation of total macroinvertebrate biomass values (Fig. 3) shows no significant changes with depth (1-way ANOVA; $p>0.08)$. In contrast, the density of invertebrates significantly declines with depth $\left(1\right.$-way ANOVA $\left.A_{i} p<0.01\right)$, from about 60 ind. $0.25 \mathrm{~m}^{-2}$ at $5 \mathrm{~m}$ depth to about 36 ind $0.25 \mathrm{~m}^{-2}$ at 10 and $18 \mathrm{~m}$ (Fig. 3). Analysis of the variations in density and biomass of the 7 most important species of this community (Fig. 3) shows 2 clear bathymetric patterns among these species: (1) a general decrease of both biomass and density with depth, exhibited by Strongylocentrotus droebachiensis and Asterias vulgaris (1-way ANOVA; $p<0.01$ in both species), and (2) a general increase of both density and biomass with depth, exhibited by Modiolus modiolus,

Table 1 Taxonomic list and bathymetric distribution (depth range) of the macroinvertebrate species found in subtidal benthic samples taken at Pemaquid Point, Maine

\begin{tabular}{|c|c|c|c|}
\hline Species & $\begin{array}{l}\text { Depth } \\
\text { range (m) }\end{array}$ & Species & $\begin{array}{l}\text { Depth } \\
\text { range }(\mathrm{m})\end{array}$ \\
\hline PORIFERA & & Pherusa plumosa (Muller) & 18 \\
\hline Scypha ciliata Fabricius & $10-18$ & Capitella capitata (Fabricius) & 18 \\
\hline Halicondria panicea (Pallas) & 5 & Pectinaria granulata (Linnaeus) & 18 \\
\hline Cliona celata Grant & 18 & ARTHROPODA (Crustacea) & \\
\hline PLATYHELMINTHES & & Cirripedia & \\
\hline Notoplana atomata (Muller) & $5-10$ & Balanus balanoides (Linnaeus) & 10 \\
\hline NEMERTEA & & Isopoda & \\
\hline Amphiphorus sp. & 18 & Idothea balthica (Pallas) & 5 \\
\hline CNIDARIA & & $\begin{array}{l}\text { Idothea phosphorea Harger } \\
\text { Amphipoda }\end{array}$ & 5 \\
\hline Anthozoa & & $\begin{array}{l}\text { Amphipoda } \\
\text { Gammarus oceanicus Segerstrale }\end{array}$ & 18 \\
\hline Metridium senile (Linnaeus) & $5-18$ & Gammarellus angulosus (Rathke) & $5-18$ \\
\hline MOLLUSCA & & Calliopius laeviusculus (Kroyer) & $5-10$ \\
\hline Gastropoda & & Jassa falcata (Montagu) & 5 \\
\hline Crepidula fornicata Linnaeus & $10-18$ & Unciola inermis (Say) & 5 \\
\hline Crepidula plana Say & $10-18$ & Caprella linearis (Linnaeus) & 5 \\
\hline Tectura (=Acmaea) testudinalis (Muller) & $5-18$ & Caprella septentrionalis Kroyer & 5 \\
\hline Lacuna vincta (Montagu) & 5 & Aeginella longicornis (Kroyer) & 5 \\
\hline Littorina littorea (Linnaeus) & 5 & Decapoda & \\
\hline Buccinum undatum (Linnaeus) & $10-18$ & $\begin{array}{l}\text { Cancer irroratus Say } \\
\text { Capoda }\end{array}$ & $5-18$ \\
\hline Nucella (= Thais) lapillus (Linnaeus) & $5-18$ & Cancer borealis Stimpson & $5-18$ \\
\hline Polyplacophora & & Hyas araneus (Linnaeus) & 5 \\
\hline Tonicella ruber (Linnaeus) & $5-18$ & Lebbeus polaris (Sabine) & 18 \\
\hline Bivalvia & & Eualus pusiolus (Kroyer) & $5-18$ \\
\hline Mytilus edulis Linnaeus & 5 & Crangon septemspinosa Say & 18 \\
\hline Modiolus modiolus (Linnaeus) & $5-18$ & Pagurus pubescens Kroyer & $5-18$ \\
\hline Hiatella arctica (Linnaeus) & $10-18$ & ECHINODERMATA & \\
\hline Mya arenaria Linnaeus & 5 & Asteroidea & \\
\hline Astarte subequilatera Sowerby & 18 & Asterias vulgaris (Verrill) & $5-18$ \\
\hline Spisula solidissima (Dillwyn) & 18 & Henricia sanguinolenta (Muller) & $5-18$ \\
\hline ANNELIDA & & Ophiuroidea & \\
\hline Polychaeta & & Ophiopholis aculeata (Linnaeus) & $5-18$ \\
\hline Lepidonotus squamatus (Linnaeus) & $5-18$ & Echinoidea & \\
\hline Harmothoe imbricata (Linnaeus) & $5-18$ & $\begin{array}{l}\text { Strongylocentrotus droebachiensis (Muller) } \\
\text { Strold }\end{array}$ & $5-18$ \\
\hline Harmothoe oerstedi (Linnaeus) & 18 & Holothuroidea & \\
\hline $\begin{array}{l}\text { Amphitrite johnstoni Malmgren } \\
\text { Pista maculata (Dalyell) }\end{array}$ & $\begin{array}{l}10-18 \\
10-18\end{array}$ & Psolus fabricii (Duben and Koren) & 10 \\
\hline Thelepus cincinnatus (Fabricius) & $\begin{array}{l}10-18 \\
10-18\end{array}$ & Cucumaria frondosa (Gunnerus) & $5-18$ \\
\hline Eulalia viridis (Linnaeus) & 5 & CHORDATA & \\
\hline Eteone longa (Fabricius) & 18 & Ascidiacea & \\
\hline Nereis pelagica Linnaeus & $5-18$ & Dendrodoa carnea (Agassiz) & $10-18$ \\
\hline Potamilla reniformes (Leuckart) & 5 & Molgula sp. & $10-18$ \\
\hline Nainereis quadricuspida (Fabricius) & 18 & & \\
\hline
\end{tabular}


Table 2. Average density (ind. $\mathrm{m}^{-2}$ ) and average biomass $\left(\mathrm{g} \mathrm{m}^{-2}\right)$ of the 22 most abundant macroinvertebrate taxa found in the 133 subtidal benthic samples collected at Pemaquid Point, Maine. In parentheses: standard error

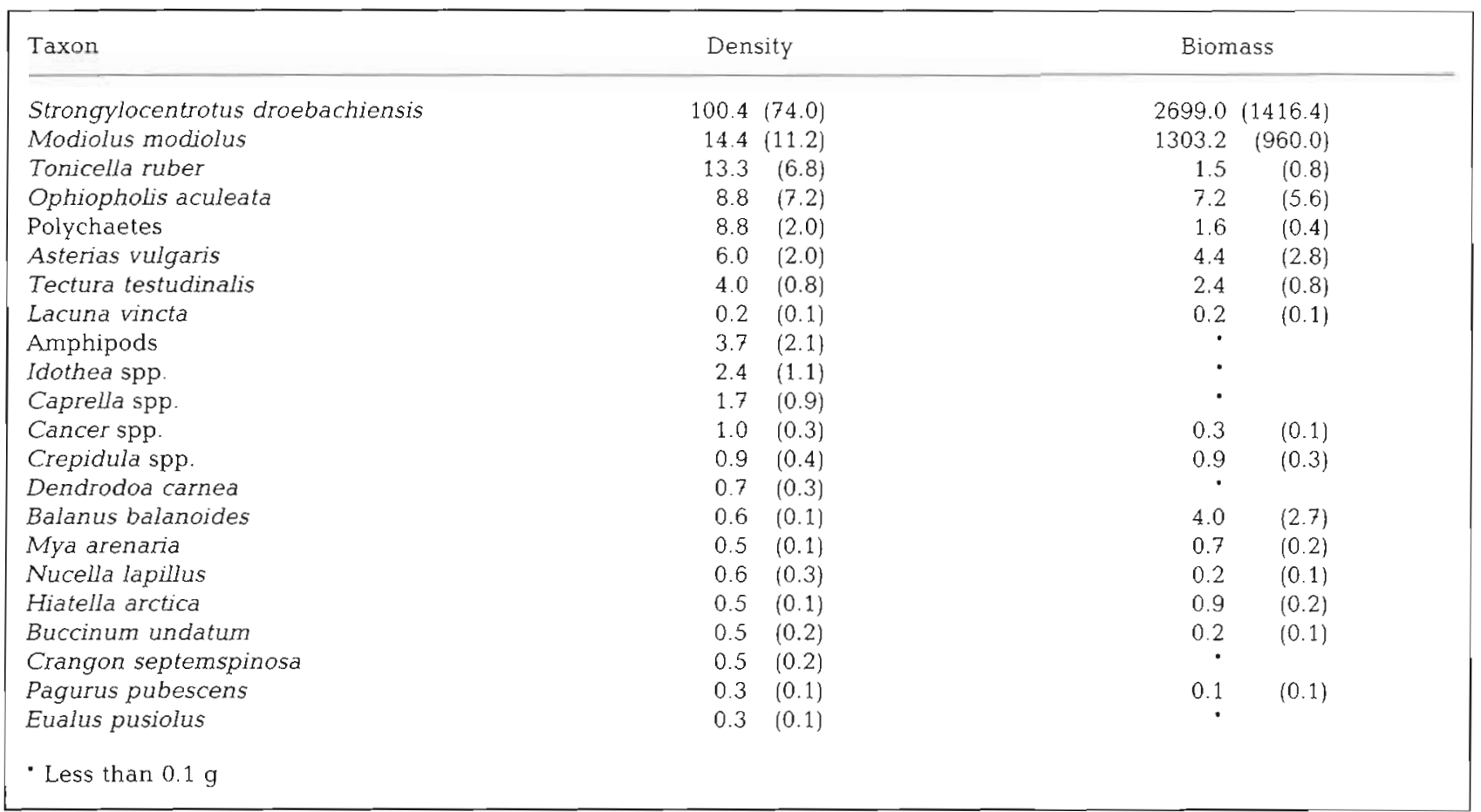

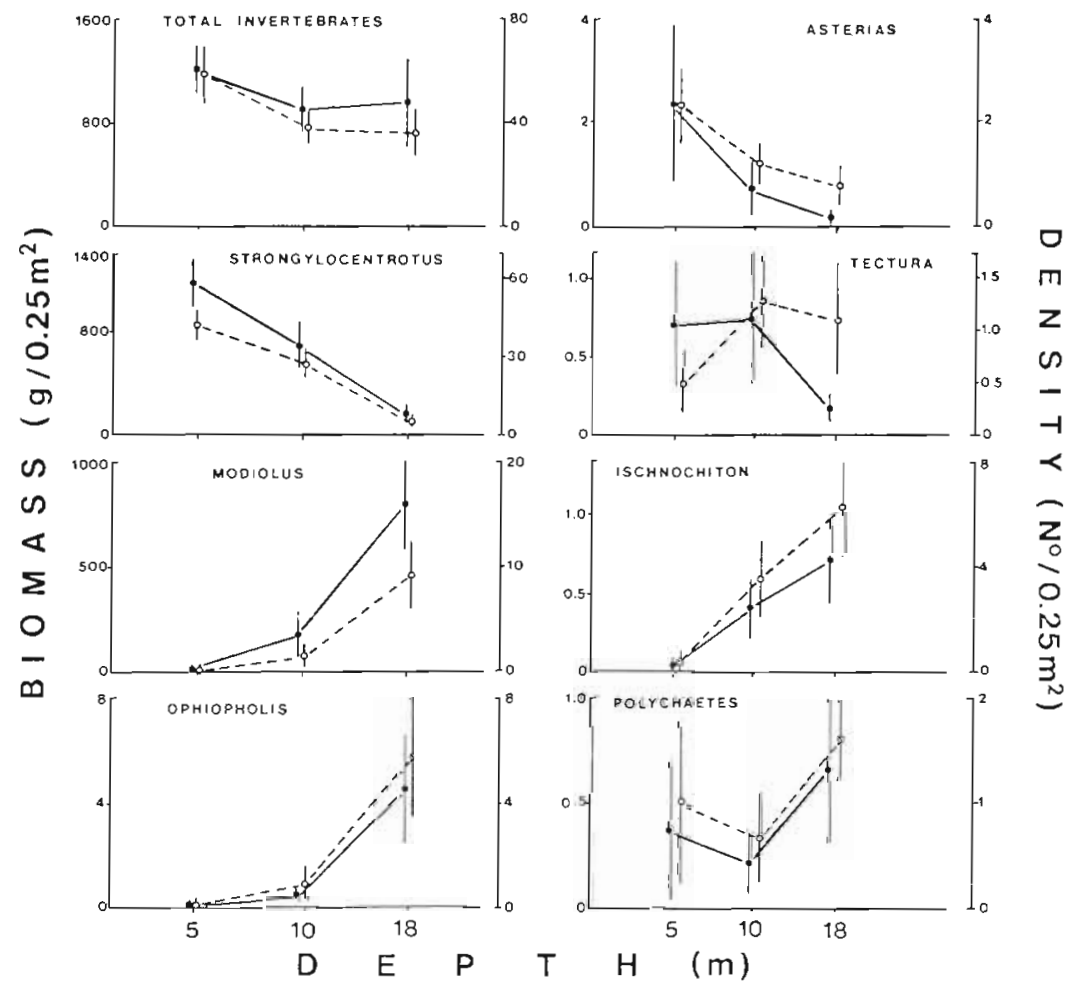

Fig 3. Bathymetric variation in biomass $(\mathrm{X} \pm 2 \mathrm{SE} ; \bullet)$ and density $\left(\overline{\mathrm{X}} \pm 2 \mathrm{SE}_{i}\right.$ o) of total invertebrates, and of the 7 most common invertebrate taxa occurring in the subtidal benthic community studied
Ophiopholis aculeata and Tonicella ruber (1-way ANOVA; $p<0.01$ in all these species). Limpet Tectura testudinalis shows a significant decline in biomass from
10 to $18 \mathrm{~m}$ depth (1-way ANOVA; $\mathrm{p}<0.01$; and a posteriori SNK test) with no significant differences between 5 and $10 \mathrm{~m}$. The bathymetric variation of the 
densities of $T$. testudinalis (Fig. 3) shows, however, a significant increase from 5 to $10 \mathrm{~m}$ (1-way ANOVA; $p<0.01$, and a posteriori SNK test). The opposite trends in biomass and density exhibited by Tectura suggest that the mean size of their individuals decrease with depth.

Polychaetes (all species grouped) show no significant bathymetric change in their abundances (both in biomass and density; 1-way ANOVA; $p>0.20$ and $\mathrm{p}>0.17$, respectively) (Fig. 3 ). The bathymetric patterns of variation observed in this group of polychaetes is probably due to their association with other benthic species such as macroalgae which were occasionally found within the quadrats sampled at $5 \mathrm{~m}$. The holdfasts of these macroalgae and the sediment accumulated among them probably provide suitable microhabitats for some polychaete species such as Nereis pelagica and Lepidonotus squamatus. A similar situation occurs at $18 \mathrm{~m}$ depth, but in this case it is the presence of Modiolus modiolus which significantly increases the opportunities of microhabitat utilization for the polychaete fauna. At this depth $(18 \mathrm{~m})$ there is also a greater number of polychaete species 12 i see Table 1) with 6 of them living exclusively within the Modiolus beds.

The cluster analysis separated the 24 commonest species of benthic invertebrates into 2 major groups (Fig. 4). The first cluster (A) is formed by 14 taxa that were most abundant at 5 and/or $10 \mathrm{~m}$ depth. The most abundant species of Group A is the sea star Asterias vulgaris which appears closely associated with some species that are typical of the intertidal-subtidal border such as Lacuna vincta, Idothea spp., and juvenile Cancer spp. Another important component of Group A in the cluster is the limpet Tectura testudinalis, which shows its maximum abundance on shallow rocks usually covered by the crustose coralline alga Clathromorphum circumscriptum (Steneck 1982; pers. obs.). This alga has recently been shown to be the dominant crustose species in shallow rocks at Pemaquid Point (Garwood et al. 1985).

The second group recognized in the cluster (Group $B ;$ Fig. 4) consists of 11 species. Their association in this group reflects that they all attain maximum abundances around the $18 \mathrm{~m}$ depth. The most conspicuous organism of this group is the horse mussel Modiolus modiolus, which commonly forms patchy clumps at around $18 \mathrm{~m}$ and is the dominant species in terms of biomass in the deepest zone (Fig. 3). Other important species of Group B are the ophiuroid Ophiopholis aculeata and the red chiton Tonicella ruber. The spatial distributions of these 2 species as well as of the remaining species forming Group B, however, are not random at the $18 \mathrm{~m}$ depth. Indeed, the distribution and abundance patterns of most of these species, as well as of a significant number of other species not included in the cluster analysis, are strongly correlated with the presence of the Modiolus clumps typical of this zone (Figs. 2 and 3). A comparative analysis of the differential distribution of macroinvertebrates found at $18 \mathrm{~m}$ depth within Modiolus beds (16 quadrats), and outside Modiolus beds (18 quadrats) shows that the invertebrate fauna inhabiting Modiolus clumps is significantly more abundant, dense, and diverse than the fauna occurring outside the beds (Table 3). Sea urchins are significantly most numerous (but not largest) within the Modiolus beds as are $O$. aculeata, $T$. ruber, and the polychaete fauna (Table 3). In the latter categories, however, both biomass and densities are significantly higher within the mussel beds than outside them (Table 3). Note, however, that at $18 \mathrm{~m}$ depth (Modiolus zone), Strongylocentrotus droebachiensis, in contrast to O. aculeata and $T$. ruber, occurs at much lower densities than in the shallow zones (Fig. 3). Similar results have been. reported by Witman (1985) for the benthic community occurring inside and outside beds of $M$. modiolus at the Isles of Shoals, Maine.

Strongylocentrotus droebachiensis does not show any significant association with any of the species analyzed in the cluster in Fig. 4. This means that the

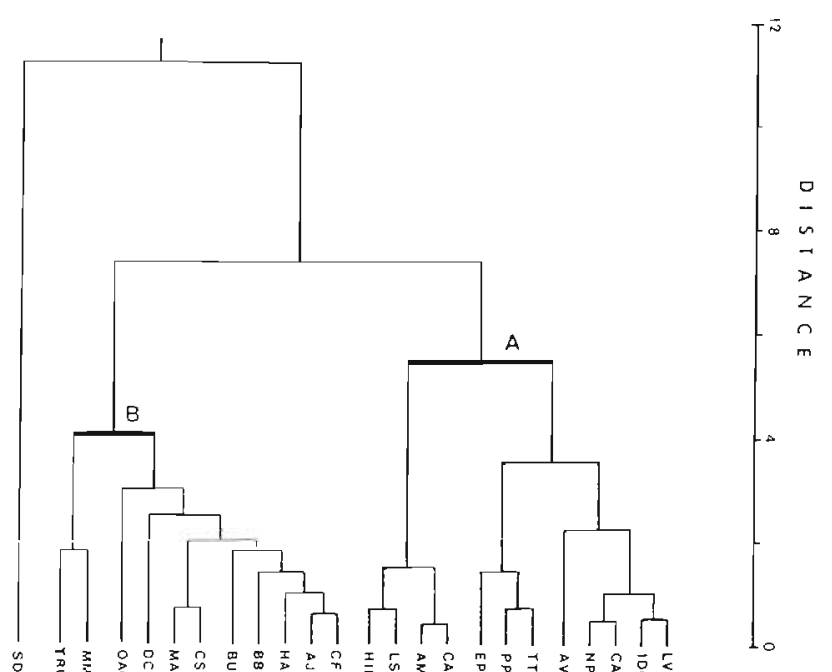

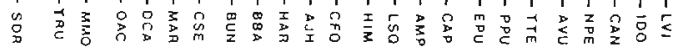

Fig 4. Dendogram of similarity (expressed as the Euclidean distance) based upon the mean density values of the 24 most common taxa found at 3 depths $(5,10$ and $18 \mathrm{~m})$ in a subtidal coralline community at Pemaquid Point, Maine. LVI = Lacuna vincta; $\mathrm{IDO}=$ Idothea $\mathrm{spp}$; $\mathrm{CAN}=$ Cancer spp.; $\mathrm{NPE}=$ Nereis pelagica; $\mathrm{AVU}=$ Astenas vulgaris $; \mathrm{TTE}=$ Tectura testudinalis; $\mathrm{PPU}=$ Pagurus pubescens; $\mathrm{EPU}=$ Eualus pusiolus; $\mathrm{CAP}=$ Caprella spp ; $\mathrm{AMP}=$ amphipods; $\mathrm{LSQ}=$ Lepidonotus squamatus; $\mathrm{HIM}=$ Harmothoe imbricata; $\mathrm{CFO}=$ Crepidula fornicata; $\mathrm{AJH}=$ Amphitrite johnston; $\mathrm{HAR}=$ Hiatella arctica; $\mathrm{BBA}=$ Balanus balanoides; $\mathrm{BUN}=$ Buccinum undatum; $\mathrm{CSE}=$ Crangon septemspinosa; $\mathrm{MAR}=$ Mya arenaria; $\mathrm{DCA}=$ Dendrodoa carnea $;$ OAC $=$ Ophiopholis aculeata; $\mathrm{MMO}=$ Modiolus modiolus; $\mathrm{TRU}=$ Tonicella ruber $\mathrm{SDR}=$ Strongylocentrotus droebachiensis 
Table 3. Comparisons of the biomass and density of invertebrates, number of species, and abundance patterns of 4 invertebrate species found in 16 and 18 quadrats of $0.25 \mathrm{~m}^{2}$ taken at $18 \mathrm{~m}$ depth inside and outside Modiolus beds, respectively. Biomass is expressed in $\mathrm{g}$, density in no. of individuals

\begin{tabular}{|c|c|c|c|}
\hline Taxon & $\begin{array}{c}\text { Inside } \\
\text { Mean } \pm \mathrm{SE}\end{array}$ & $\begin{array}{c}\text { Outside } \\
\text { Mean } \pm \text { SE }\end{array}$ & t-statistic \\
\hline \multicolumn{4}{|l|}{ Invertebrates } \\
\hline Biomass & $1590.8 \pm 250.5$ & $295.2 \pm 56.6$ & $5.325^{\cdots}$ \\
\hline Density & $53.5 \pm 6.0$ & $14.4 \pm 2.4$ & $5.685^{\cdots}$ \\
\hline No. of species & $9.9 \pm 0.9$ & $3.5 \pm 0.6$ & $5.466^{\cdots}$ \\
\hline \multicolumn{4}{|c|}{ Strongylocentrotus droebachiensis } \\
\hline Biomass & $164.6 \pm 46.8$ & $145.2 \pm 32.8$ & 0.354 \\
\hline Density & $8.0 \pm 1.6$ & $3.4 \pm 0.7$ & $2.744 \cdots$ \\
\hline \multicolumn{4}{|c|}{ Ophiopholis aculeata } \\
\hline Biomass & $7.5 \pm 2.3$ & $1.3 \pm 2.9$ & $3.689^{*} \cdot$ \\
\hline Density & $9.7 \pm 2.5$ & $1.2 \pm 0.4$ & $3.689^{\circ}$ \\
\hline \multicolumn{4}{|l|}{ Tonicella ruber } \\
\hline Biomass & $0.9 \pm 0.2$ & $0.3 \pm 0.1$ & $2.524^{\bullet}$ \\
\hline Density & $8.6 \pm 1.6$ & $2.6 \pm 0.5$ & $3.734^{\cdots}$ \\
\hline \multicolumn{4}{|l|}{ Polychaetes } \\
\hline Biomass & $0.9 \pm 0.4$ & $0.1 \pm 0.05$ & $1.989^{\circ}$ \\
\hline Density & $4.1 \pm 1.1$ & $1.2 \pm 0.4$ & $2.651^{\cdots}$ \\
\hline$\cdot p<0.05 ; \cdots p<$ & & & \\
\hline
\end{tabular}

abundance patterns of sea urchins do not seem to be correlated with any other invertebrate species pattern.

\section{Seasonal patterns}

Temporal variations in the occurrence of all macroinvertebrate species found in the 9 subtidal seasonal samples taken at Pemaquid Point are summarized in Table 4 . Of the total of 59 species collected in all these samples, $13(22 \%)$ of them were consistently found in all seasonal samples and seemingly constitute permament populations in this community (Crepidula fornicata, Tectura testudinalis, Tonicella ruber, Modiolus modiolus, Hiatella arctica, Lepidonotus squamatus, Harmothoe imbricata, Nereis pelagica, Balanus balanoides, Calliopius laeviusculus, Asterias vulgaris, Ophiopholss aculeata and Strongylocentrotus droebachiensis). As noted above, these are also the most abundant species in this community (Table 2). The presence of the 46 remaining species was restricted to some months or seasons of the year (Table 4). Most were of a rare occurrence in the samples and generally were represented by few individuals. Some show, however, a consistent temporal pattern of occurrence in the samples (e.g. Nucella lapillus, Idothea spp., Pagurus pubescens and Jassa falcata which occur in the summer samples; Table 4), while others do not exhibit any clear seasonal pattern.

An analysis of the temporal variation of the total number of species found in each of the 9 seasonal samples (Table 4) shows a clear pattern, with maximum values of species richness occurring in summer samples intermediate values during the spring samples, and minimum values in the fall and winter samplings. Since sample size (effort) was quite similar among seasons (see Table 4) the diversity pattern found does not represent a sampling artifact.

Temporal variations in biomass and density of the macroinvertebrate fauna is shown in Fig. 5. In general, no significant change was observed for the invertebrate biomass values at any of the 3 depths (1-way ANOVA $_{i} p=0.52, p=0.23$, and $p=0.62$ at 5,10 , and $18 \mathrm{~m}$, respectively).

Analysis of the temporal density values, however, showed (Fig. 5) a significant pattern of variation at $5 \mathrm{~m}$ depth, with one statiscally significant peak in October 1984 (1-way ANOVA; $p<0.03$, a posteriori SNK test). No peak, however, was observed in October 1986. The density values observed for 10 and $18 \mathrm{~m}$ depth did not disclose any clear significant temporal pattern of variation $(1-$ way ANOVA; $p=0.57$ and $p=0.90$, respectively; Fig. 5).

Analysis of the temporal changes in the abundance of Strongylocentrotus droebachiensis shows that at $5 \mathrm{~m}$ depth there was a significant increase in density in October 1984 (1-way ANOVA; $\mathrm{p}<0.03$ and a posteriori SNK test; Fig. 6). With respect to biomass changes at $5 \mathrm{~m}$ (Fig. 6), no significant differences were detected among these values (1-way ANOVA; $p=0.08$ ). No 
Table 4. Presence of macroinvertebrate species found in 9 seasonal subtidal transects carried out at Pemaquid Point, Maine. Presence $(\mathrm{X})$ indicates ocurrence of a given species in at least one of the 16 to 30 quadrats of $0.25 \mathrm{~m}^{2}$ sampled in each transect

\begin{tabular}{|c|c|c|c|c|c|c|c|c|c|}
\hline \multirow[t]{2}{*}{ Taxon } & \multicolumn{2}{|c|}{1984} & \multicolumn{3}{|c|}{1985} & \multicolumn{4}{|c|}{1986} \\
\hline & Aug & Oct & May & Sep & Nov & Feb & Jun & Aug & Oct \\
\hline \multicolumn{10}{|l|}{ PORIFERA } \\
\hline Scypha ciliata & & & & $\mathrm{X}$ & & & & $\mathrm{x}$ & \\
\hline Halicondria panicea & & $\mathrm{X}$ & $x$ & $\mathrm{x}$ & $\mathrm{x}$ & & $\mathrm{x}$ & & $X$ \\
\hline Cliona celata & $\mathrm{X}$ & & & & & & & & $\mathrm{x}$ \\
\hline \multicolumn{10}{|l|}{ PLATYHELMINTHES } \\
\hline Notoplana atomata & $\mathrm{x}$ & & & $\mathrm{X}$ & & & & & \\
\hline \multicolumn{10}{|l|}{ NEMERTEA } \\
\hline Amphiphorus sp. & & & & $X$ & & & & $x$ & \\
\hline \multicolumn{10}{|l|}{ CNIDARIA } \\
\hline \multicolumn{10}{|l|}{ Anthozoa } \\
\hline Metridium senile & $\mathrm{x}$ & & $x$ & & & & $\mathrm{x}$ & $\mathrm{x}$ & \\
\hline \multicolumn{10}{|l|}{ MOLLUSCA } \\
\hline \multicolumn{10}{|l|}{ Gastropoda } \\
\hline Crepidula fornicata & $x$ & $\mathrm{X}$ & $x$ & $\mathrm{x}$ & $\mathrm{X}$ & $\mathrm{x}$ & $x$ & $x$ & $\mathrm{X}$ \\
\hline Crepidula plana & $\mathrm{X}$ & $x$ & & $x$ & & $x$ & & $\mathrm{X}$ & $\mathrm{X}$ \\
\hline Tectura testudinalis & $x$ & $\mathrm{x}$ & $\mathrm{X}$ & $x$ & $\mathrm{x}$ & $\mathrm{X}$ & $\mathrm{x}$ & $x$ & $\mathrm{x}$ \\
\hline Lacuna vincta & & & & $x$ & & & & & \\
\hline Littorina littorea & $\mathrm{x}$ & & & $\mathrm{x}$ & $\mathrm{X}$ & & & $x$ & \\
\hline Buccinum undatum & $\mathrm{X}$ & $\mathrm{X}$ & & $x$ & & & & & $X$ \\
\hline Nucella lapillus & $\mathrm{X}$ & $\mathrm{X}$ & & $x$ & $\mathrm{x}$ & & $x$ & $\mathrm{x}$ & \\
\hline \multicolumn{10}{|l|}{ Polyplacophora } \\
\hline Tonicella ruber & $\mathrm{x}$ & $\mathrm{X}$ & $\mathrm{x}$ & $\mathrm{x}$ & $\mathrm{X}$ & $\mathrm{x}$ & $\mathrm{x}$ & $x$ & $\mathrm{X}$ \\
\hline \multicolumn{10}{|l|}{ Bivalvia } \\
\hline Mytilus edulis & & & & $\mathrm{X}$ & & $x$ & & & \\
\hline Modiolus modiolus & $x$ & $x$ & $\mathrm{X}$ & $x$ & $\mathrm{x}$ & $\mathrm{X}$ & $x$ & $x$ & $\mathrm{x}$ \\
\hline Hiatella arctica & $\mathrm{x}$ & $\mathrm{X}$ & $\mathrm{X}$ & $\mathrm{x}$ & $x$ & $x$ & $x$ & $x$ & $\mathrm{X}$ \\
\hline Mya arenaria & & & & $\mathrm{x}$ & & & & & \\
\hline Astarte subequilatera & & & & $\mathrm{x}$ & & & & & \\
\hline Spisula solidissima & & & & & & & & $x$ & \\
\hline \multicolumn{10}{|l|}{ ANNELIDA } \\
\hline \multicolumn{10}{|l|}{ Polychaeta } \\
\hline Lepidonotus squamatus & $\mathrm{x}$ & $x$ & $x$ & $x$ & $\mathrm{X}$ & $\mathrm{x}$ & $X$ & $x$ & $\mathrm{X}$ \\
\hline Harmothoe imbricata & $x$ & $x$ & $\mathrm{X}$ & $\mathrm{x}$ & $x$ & $x$ & $\mathrm{X}$ & $\mathrm{X}$ & $\mathrm{X}$ \\
\hline Harmothoe oerstedi & & & & & & & & $x$ & \\
\hline Amphitrite johnstoni & $\mathrm{X}$ & $\mathrm{X}$ & $\mathrm{X}$ & $\mathrm{x}$ & $x$ & & $\mathrm{X}$ & $x$ & $\mathrm{X}$ \\
\hline Pista maculata & & & & & & $\mathrm{X}$ & & & \\
\hline Thelepus cincinnatus & & & & & & $x$ & & & \\
\hline Eulalia viridis & & & & & $\mathrm{x}$ & & & & \\
\hline Eteone longa & & & & & $\mathrm{X}$ & & & $\mathrm{X}$ & \\
\hline Nereis pelagica & $x$ & $\mathrm{X}$ & $\mathrm{X}$ & $\mathrm{x}$ & $x$ & $x$ & $x$ & $\mathrm{x}$ & $x$ \\
\hline Potamilla reniformes & & & & & $x$ & & $\mathrm{x}$ & & \\
\hline Nainereis quadricuspida & & & & & $\mathrm{x}$ & & & & \\
\hline Pherusa plumosa & & & $\mathrm{x}$ & & & $\mathrm{X}$ & & & \\
\hline Capitella capitata & & & & & & $x$ & & & \\
\hline Pectinaria granulata & & & $\mathrm{x}$ & & & & & $\mathrm{X}$ & \\
\hline \multicolumn{10}{|l|}{ ARTHROPODA (Crustacea) } \\
\hline \multicolumn{10}{|l|}{ Cirripedia } \\
\hline Balanus balanoides & $\mathrm{X}$ & $x$ & $\mathrm{X}$ & $X$ & $x$ & $x$ & $\mathrm{X}$ & $\mathrm{X}$ & $x$ \\
\hline \multicolumn{10}{|l|}{ Isopoda } \\
\hline Idothea bolthica & & $\mathrm{X}$ & & $\mathrm{x}$ & & & & $\mathrm{x}$ & $\mathrm{X}$ \\
\hline Idothea phosphorea & $x$ & & & $x$ & & & $\mathrm{x}$ & $x$ & \\
\hline
\end{tabular}


Table 4 (continued)

\begin{tabular}{|c|c|c|c|c|c|c|c|c|c|}
\hline \multirow[t]{2}{*}{ Taxon } & \multicolumn{2}{|c|}{1984} & \multicolumn{3}{|c|}{1985} & \multicolumn{4}{|c|}{1986} \\
\hline & Aug & Oct & May & Sep & Nov & Feb & Jun & Aug & Oct \\
\hline \multicolumn{10}{|l|}{ Amphipoda } \\
\hline Gammarus oceanicus & $\mathrm{x}$ & & $\mathrm{x}$ & $\mathrm{X}$ & $\mathrm{x}$ & & & $\mathrm{x}$ & \\
\hline Gammarellus angulosus & & $x$ & & $\mathrm{x}$ & & & $\mathrm{x}$ & & \\
\hline Calliopius laeviusculus & $\mathrm{x}$ & $\mathrm{x}$ & $\mathrm{x}$ & $\mathrm{x}$ & $\mathrm{x}$ & $\mathrm{x}$ & $\mathrm{x}$ & $\mathrm{x}$ & $\mathrm{x}$ \\
\hline Jassa falcata & $\mathrm{x}$ & & & $\mathrm{x}$ & & & $\mathrm{x}$ & $\mathrm{x}$ & \\
\hline Unciola inermis & & & & $\mathrm{x}$ & & & & & $\mathrm{x}$ \\
\hline Caprella linearis & $\mathrm{x}$ & $\mathrm{x}$ & $\mathrm{x}$ & & $\mathrm{x}$ & $\mathrm{x}$ & $\mathrm{x}$ & $\mathrm{x}$ & \\
\hline Caprella septentrionalis & $\mathrm{x}$ & $\mathrm{x}$ & & $\mathrm{x}$ & & & $\mathrm{x}$ & & \\
\hline Aeginella longicornis & $\mathrm{x}$ & & & & & & & $\mathrm{x}$ & \\
\hline \multicolumn{10}{|l|}{ Decapoda } \\
\hline Cancer spp. & $\mathrm{x}$ & $\mathrm{x}$ & & $\mathrm{x}$ & $\mathrm{x}$ & & $\mathrm{x}$ & $\mathrm{x}$ & $\mathrm{x}$ \\
\hline Hyas araneus & $\mathrm{x}$ & $\mathrm{x}$ & & & & & & $\mathrm{x}$ & \\
\hline Lebbeus polaris & & $\mathrm{x}$ & & & & & & & \\
\hline Eualus pusiolus & & & & & & $\mathrm{x}$ & $x$ & & $\mathrm{x}$ \\
\hline Crangon septemspinosa & & & & & & & $\mathrm{x}$ & $\mathrm{x}$ & \\
\hline Pagurus pubescens & $\mathrm{x}$ & & & $x$ & & & $x$ & & \\
\hline $\begin{array}{l}\text { Asteroidea } \\
\text { Asterias vulgaris }\end{array}$ & $\mathrm{x}$ & $\mathrm{x}$ & $\mathrm{x}$ & $\mathrm{x}$ & $\mathrm{x}$ & $\mathrm{x}$ & $\mathrm{x}$ & $\mathrm{x}$ & $x$ \\
\hline Henricia sanguinolenta & & $\mathrm{x}$ & & & $x$ & & & $\mathrm{x}$ & \\
\hline \multicolumn{10}{|l|}{ Ophiuroidea } \\
\hline Ophiopholis aculeata & $x$ & $x$ & $x$ & $\mathrm{x}$ & $\mathrm{x}$ & $\mathrm{x}$ & $\mathrm{x}$ & $\mathrm{x}$ & $\mathrm{x}$ \\
\hline \multicolumn{10}{|l|}{ Echinoidea } \\
\hline $\begin{array}{l}\text { Strongylocentrotus } \\
\text { droebachiensis }\end{array}$ & $\mathrm{x}$ & $\mathrm{x}$ & $\mathrm{x}$ & $x$ & $\mathrm{x}$ & $\mathrm{x}$ & $\mathrm{x}$ & $\mathrm{x}$ & $\mathrm{x}$ \\
\hline \multicolumn{10}{|l|}{ Holothuroidea } \\
\hline Psolus fabricii & $\mathrm{x}$ & & $\mathrm{x}$ & & & & & $\mathrm{x}$ & \\
\hline Cucumaria frondosa & $\mathrm{x}$ & & $\mathrm{x}$ & & $\mathrm{x}$ & & & $\mathrm{x}$ & $\mathrm{x}$ \\
\hline \multicolumn{10}{|l|}{$\begin{array}{l}\text { CHORDATA } \\
\text { Ascidiacea }\end{array}$} \\
\hline $\begin{array}{l}\text { Ascidiacea } \\
\text { Dendrodoa carnea }\end{array}$ & $x$ & $\mathrm{x}$ & & & $\mathrm{x}$ & $x$ & & $\mathrm{x}$ & \\
\hline Molgula sp. & $\mathrm{x}$ & & $\mathrm{x}$ & & & & & & \\
\hline No. of species & 34 & 27 & 23 & 35 & 27 & 22 & 27 & 37 & 23 \\
\hline No, of quadrats $\left(0.25 \mathrm{~m}^{2}\right)$ sampled & 14 & 27 & 20 & 12 & 12 & 12 & 12 & 12 & 12 \\
\hline
\end{tabular}

significant density change was observed at $10 \mathrm{~m}$ depth (1-way ANOVA; $p=0.11$; Fig. 6). A similar pattern was found with respect to the biomass values. In this case, however, a significant decrease was observed in October 1984 and in August 1986 (1-way ANOVA; $\mathrm{p}<0.06$ and a posteriori SNK test). The temporal variation in the abundance of sea urchins at $18 \mathrm{~m}$ (Fig. 6), both in density and biomass, did not disclose any clear pattern, and no statistically significant differences were detected among these values (1-way ANOVA; $p=0.67$ and $p=0.81$ for density and biomass, respectively).

No clear temporal patterns in density and biomass were observed for Modiolus modiolus at 10 and $18 \mathrm{~m}$ depths. Moreover, no significant differences were observed among the density and biomass values at both depths during the seasonal samplings (1-way ANOVA; $p=0.23$ and $p=0.22$ for density and biomass values respectively at $10 \mathrm{~m}$; and $p=0.60$ and $p=0.85$ for density and biomass values respectively at $18 \mathrm{~m}$ depth). These results, however, should be taken cautiously, because they could represent an artifact of the random sampling associated with the extremely patchy spatial distribution of Modiolus.

\section{DISCUSSION}

A total of 60 invertebrate species were recorded in the benthic samples obtained from the subtidal crustose coralline community studied at Pemaquid Point, Maine. Numerous diving observations by one of the authors (F.P.O.) along the coast of Maine indicate that these species seem to constitute the typical invertebrate fauna of horizontal and sloping rock substrates of subtidal environments of this coast. Other conspicuous habitats of these environments such as vertical and 


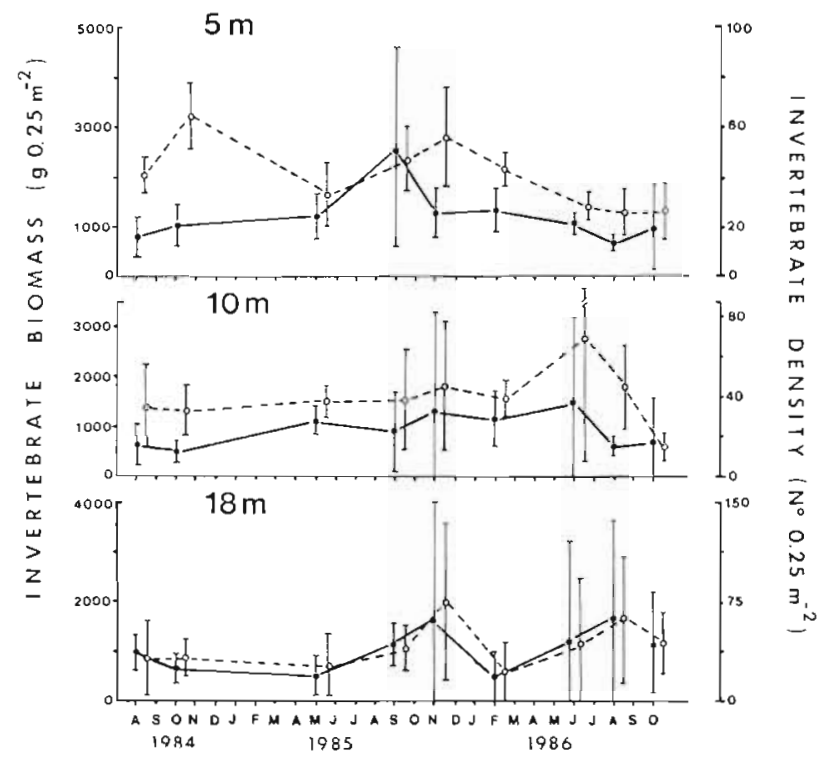

Fig 5. Temporal changes in biomass $\left(\overline{\mathrm{X}} \pm 2 \mathrm{SE}_{;} \bullet\right)$ and density $(\overline{\mathrm{X}} \pm 2 \mathrm{SE} ; 0)$ of macroinvertebrates at 3 depths $(5,10$ and $18 \mathrm{~m}$ )

undercut rocky surfaces were not investigated in this study. They generally harbor different kind of benthic communities, usually dominated by sponges and tunicates. Recently, such communities have been studied by Noble et al. (1976), Sebens (1982, 1986a, b), Logan et al. (1984) and Witman (1985).

Relatively little is known about rocky sublittoral benthic communities of the Gulf of Maine, particularly regarding their composition and community structure. Comparable sublittoral studies conducted by Noble et al. (1976) and Logan et al. $(1983,1984)$ in the Bay of Fundy, Canada, have recognized the existence of 2 distinctive types of benthic communities occupying different microhabitats: the crustose coralline algae community, which is dominant on upper surfaces from 0 to $20 \mathrm{~m}$ depth, and the community dominated by the brachiopod Terebratulina septentrionalis. Communities dominated by this brachiopod occur cryptically on the undersides of rocks and crevices of the upper sublittoral zone dominated by crustose algae $(0$ to $20 \mathrm{~m}$ depth), and on upper surfaces of rocks and ledges at greater depths (> $20 \mathrm{~m}$ ) (Noble et al. 1976 , Logan et al. 1983, 1984). Logan et al. (1983) reported a total of 84 species of invertebrates inhabiting crustose coralline communities in the Bay of Fundy; most of these species were the same as those reported in this study. The differences in the specific composition and total number of species between this study and of Logan et al. (1983) is probably due to the fact that those authors included invertebrate species found both on horizontal rocky surfaces and vertical walls. A similar situation occurs when our results are compared with those reported by Witman (1985) for the rocky sublittoral zone off the Isles of Shoals, Maine. He reported a total of 171 invertebrate species of which 80 were frequently found in the benthic samples. Witman's (1985) study showed strong similarities in community composition with this study. Most of the invertebrate species found at Pemaquid Point were also recorded in similar subtidal habitats off the Isles of Shoals (see Table 1 in this study and Table A1 in Witman 1985). Furthermore, horizontal habitats studied by Witman (1985) and in this study were both dominated by sea urchins, horse mussels, chitons and limpets. The observed differences in number of species with Witman's (1985) study are probably attributable to the greater depth of the Isles of Shoals communities $(30 \mathrm{~m})$, and to the inclusion of the invertebrate fauna typical of vertical walls in that study.

Although crustose coralline communities have often been considered systems of very low diversity and productivity (for which they have been named 'barren grounds' or 'barren communities', see Lawrence 1975 for review), the results of this study and those cited above demonstrate that, despite their low primary productivity, coralline communities are ecological systems with relatively high species diversity and secondary

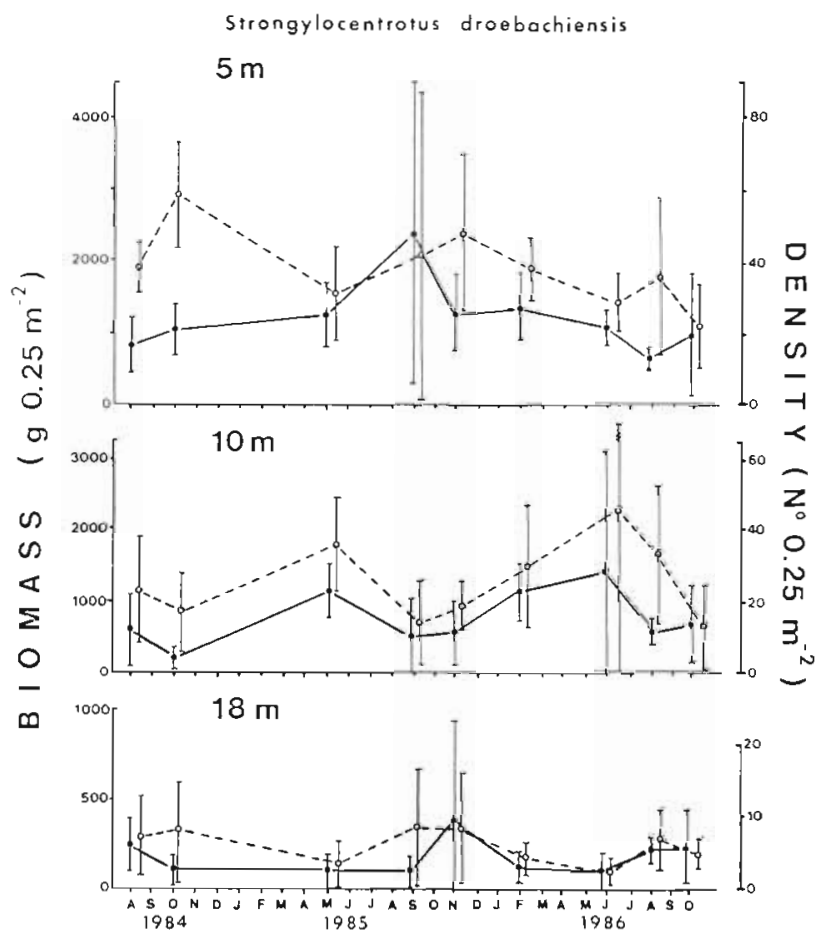

Fig 6. Strongylocentrotus droebachiensis. Temporal changes in biomass $\left(\overline{\mathrm{X}} \pm 2 \mathrm{SE}_{\mathrm{i}} \bullet\right)$ and density $\left(\overline{\mathrm{X}} \pm 2 \mathrm{SE}_{\mathrm{O}} \mathrm{O}\right)$ at 3 depths (5, 10 and $18 \mathrm{~m})$ 
productivity, sometimes comparable to systems dominated by kelps (e.g. Shannon's H diversity index for macroinvertebrates $=1.83$ in this study and $H=2.23$ in Ojeda \& Santelices 1984). Accordingly, the term 'barren ground' should be used more cautiously, only in reference to the general absence of macroalgae due to heavy overgrazing by sea urchins. In this study we use the term 'crustose coralline communities' because we believe it clearly denotes the most evident algal feature of these systems.

This study shows clear bathymetric trends in the composition and abundance of macroinvertebrates. The observed patterns of species distribution, however, are strongly influenced by the particular spatial distribution of the 2 most abundant invertebrate species in this community: Strongylocentrotus droebachiensis and Modiolus modiolus (Table 2). The shallow zone ( 3 to $12 \mathrm{~m}$ depth) is mostly dominated by sea urchins which from dense aggregations of up to 240 ind. $\mathrm{m}^{-2}$, and comprise more than $90 \%$ of the total biomass at these depths (Table 2). This zone is strongly affected by the grazing activities of sea urchins, which at these high densities are able to limit the distribution and abundance of almost any fleshy macroalgae. Experimental removals of green urchins conducted by Breen \& Mann (1976) in Nova Scotia, and by Himmelman et al. (1983) in the St. Lawrence estuary, have demonstrated their ecological importance in determining diversity, abundance and distributional patterns of macroalgal species. The recent mass mortalities of urchins and the dramatic growth of fleshy algae along the Nova Scotia eastern coasts (Miller \& Colodey 1983, Scheibling \& Stephenson 1984, Scheibling 1986) have confirmed, on a large scale, the importance of sea urchins in rocky sublittoral environments. Crustose coralline algae, however, remain relatively unaffected by sea urchins because of their effective structural defense mechanisms against grazing (Paine \& Vadas 1969, Steneck 1982, 1986, Johnson \& Mann 1986a), thus monopolizing most of the primary substrate of rocky surfaces of sublittoral habitats, as observed in this study.

Most of the invertebrate species found exclusively at $5 \mathrm{~m}$ depth were typical intertidal forms that extended their distribution to the shallowest sublittoral zone (e.g. gastropod mollusks and amphipods), or were species closely related to the macroalgal turf of this shallow zone (e.g. polychaetes and small clams). The existence of this macroalgal turf as well as of a narrow band of kelp in the uppermost portion of the sublittoral zone 10 to $2 \mathrm{~m}$ below MLWL) is due to the general absence of sea urchins in this zone. Strong water movements, and wave turbulence, in addition to sea bird predation (Himmelman \& Steele 1971) are probably major factors limiting the distribution of sea urchins into this shallow- est subtidal zone, and the low intertidal zone as well (Himmelman 1986). The large aggregations of urchins in the shallow zone $(5 \mathrm{~m}$ depth) were commonly observed feeding on drift algae as reported elsewhere (Lawrence 1975, Johnson \& Mann 1982, Himmelman 1986, Sebens 1986a).

The reduction in number of species, and in abundance of invertebrates observed in the mid-sublittoral zone (9 to $11 \mathrm{~m}$ depth), is probably a result of intense grazing by Strongylocentrotus droebachiensis. The general absence of particular microhabitats that usually provide spatial refuges from predators may also contribute to this phenomenon. Indeed, the bedrock in the mid-sublittoral zone is markedly flat with few topographic irregularities such as large crevices and small cracks. Such spatial refuges are particularly relevant because sea urchins also feed upon a number of invertebrate species (Himmelman et al. 1983, Witman 1985, Sebens 1986a). Sea urchins, therefore, in addition to the mobile predator fauna of these environments, may be also exerting important influences in the abundance and distributional patterns of invertebrates in this community (Himmelman \& Steele 1971, Keats et al. 1984, Witman 1985, Johnson \& Mann 1986b, Ojeda \& Dearborn unpubl.).

In the Gulf of Maine, settlement of Strongylocentrotus droebachiensis larvae has been shown to be random (Harris et al. 1984). The relative scarcity of sea urchins found in the deeper zone (16 to $20 \mathrm{~m}$ depth; Fig. 3) is probably related to differential survival. Low survivorship of urchins in this zone could be a result of low availability of food, or of heavy mortality exerted by the abundant mobile predators found at these depths (Ojeda \& Dearborn unpubl.).

The change in species composition of macroinvertebrates observed at the deeper zone (18 $\mathrm{m}$ depth) as well as the marked increase in species richness (Table 1) were associated with increases in the abundance of Modiolus modiolus occurring in this zone (i.e. to the large numbers of individual Modiolus clumps; Fig. 3). Indeed, most of these macroinvertebrate species occur exclusively inside Modiolus beds (Table 3). A similar phenomenon has been documented in other populations of M. modiolus. Brown \& Seed (1977), for example, found 90 invertebrate taxa associated with subtidal clumps of $M$ modiolus in Northern Ireland. Similarly, subtidal Modiolus beds off the Isles of Shoals studied by Witman (1985) contained significantly higher densities of invertebrates (infauna) than other subtidal habitats.

Experimental studies conducted by Witman (1985) on the ecological causes of such differential distribution and abundance of invertebrates have shown a functionally important role of Modiolus beds as spatial refuges from predators. This role, which is a by-product 
of the structural complexity of mussel beds (Witman 1985, Suchaneck 1986), is particularly significant because it has been suggested that predation and grazing by urchins are major determinants of community structure in New England rocky subtidal habitats (Witman 1985).

Modiolus clumps, however, also provide suitable and stable microhabitats for numerous invertebrates that are probably more important for specific life history processes of these species than for protection from predators (Brown \& Seed 1977). This is probably the case with some infaunal organisms such as polychaetes and clams inhabiting the sediment and detritus that usually accumulate at the base of the mussels (Witman 1985. Suchaneck 1986, pers. obs.). These kinds of microhabitats are relatively rare on rocky substrates, which explains why some of these species were exclusively found inside the mussel beds. Alternatively, the shells and the intertices between the mussels, as well as the weft of byssus threads, may represent optimal feeding grounds for some epifaunal species. This is likely the situation occurring with some suspension and filter feeders such as barnacles, tunicates and ophiuroids which exploit the turbulences and slow water flows created by mainstream currents colliding with individual mussels (Connell 1972, Wainwright \& Koehl 1976). Furthermore, because of the 3 dimensional asymmetric configuration of individual mussel clumps (i.e. mussels oriented in different directions) those turbulences (eddies) may also enhance retention of food particles inside the clumps, favoring prey capture in suspension-feeding organisms such as some octocorals and ophiuroids (Patterson 1984, Mary W. Wright pers. comm.).

Although the experimental results presented by Witman (1985) support the predation-refuge hypothesis, additional experiments to test the hypothesis of microhabitat selection are necessary before any conclusion is made on the causes explaining this phenomenon.

The invertebrate community, in general, did not show drastic temporal changes in abundance of organisms (biomass and density; Fig. 5) during the time span of this study $(27 \mathrm{mo})$. However, it could be possible that on a longer temporal scale, these communities might be drasticaliy affected by exceptional climatic events such as violent storms or hurricanes. Along the bathymetric gradient, the general temporal patterns in biomass and density observed in this subtidal community were mostly determined by the abundance pattern exhibited by Strongylocentrotus droebachiensis (at 5 and $10 \mathrm{~m}$ depth), and by Modiolus modiolus in the deeper zone (18 $\mathrm{m}$ depth) (Fig. 3). The only significant increase in the abundance (density) of macroinvertebrates was observed in October 1984 at $5 \mathrm{~m}$ depth (Fig.
5). It was due to a significant increase in density of $S$. droebachiensis (Fig. 6).

Population dynamic of sea urchins along this coast most likely represents population changes resulting from the combined and compensatory interactions of several processes involving recruitment, migration, and differential predation. Bathymetric migrations, for example, probably occur in response to the more severe climatic conditions observed in the shallowest subtidal zone during winter. Himmelman (1986) found that populations of green sea urchins of exposed locations in Newfoundland migrate in winter to greater depths where they encounter more favourable conditions than shallow habitats. On the other hand, seasonal changes in the abundance of sea urchins in the shallowest zone may well be the result of differential mortalities primarily affecting the juveniles. Drastic temperature changes and severe storms occurring in late fall and winter along New England coasts could account for seasonal mortalities of small sea urchins. Similarly, predation exerted by benthic mobile predators (lobsters, crabs and fishes) has also been shown to drastically affect the abundance and distribution patterns of sea urchins populations in these environments (Himmelman \& Steele 1971, Johnson \& Mann 1982, Keats et al. 1984, 1986, Witman 1985, Himmelman 1986, Ojeda 1987). Despite all these antecedents, at present, the relative importance of these processes is unclear.

The number of macroinvertebrate species (species richness) showed marked seasonal variations during this study. Maximum values were observed during summer, intermediate values in fall and spring, and a minimum value in winter of 1986 (Table 4). Most of these seasonal changes, however, were due to temporal variations in the occurrence of rare species (Table 4). In contrast, the most conspicuous and abundant species, such as sea urchins, mussels, limpets, chitons and sea stars, were permanent members of this community (Table 4).

The observed seasonal pattern of species richness, therefore, could be ascribed to seasonal inshore movements of some migratory invertebrate species (e.g. shrimps, amphipods), and to seasonal increase in the activity of other species such as gastropods mollusks associated with increasing temperature.

In summary, the results of this study agree with other studies in documenting well-defined patterns of zonation of benthic macroinvertebrates species inhabiting crustose coralline communities of shores of the Gulf of Maine (Noble et al. 1976, Logan et al. 1983, 1984, Sebens $1985,1986 a$, Witman 1985). These patterns are the result of the combined effect of several ecological factors such as predation, competition, and physical disturbances (Sebens 1985, 1986b. Witman 1985, Ojeda 1987). 
Acknowledgements. This paper represents a portion of the Ph. $D$. dissertation submitted by F. P. O to the Department of Zoology, University of Maine, Orono. Drs Hugh DeWitt, Bill Glanz, Irv Kornfield, Robert Scheibling, Robert Steneck, Les Watling and Dave Tapley provided critical comments and valuable suggestions that greatly improved the manuscript. We appreciate the diving assistance and logistic support given by Mike Dunn, Phil Garwood, Chuck Gregory, Jef Guy, Sally Hacker, David Knowles, Mike Lesser, Curt Moody, Greg Podniesisnski, Baron Richardson, Kevin Scully, Dave Tapley, Robert Vadas, Rick Wahle, and Mary Wright. This work was supported by an ODEPLAN Chilean Scholarship, a University Graduate Research Fellowship of the University of Maine, and by grants from the Migratory Fish Research Institute (MFRI), the Graduate Student Board (GSB), the Department of Zoology awarded to F. P. O., and by the Center for Marine Studies, and the Ira C. Darling Center, all of them of the University of Maine.

\section{LITERATURE CITED}

Ayling, A. M. (1981). The role of biological disturbance in temperate subtidal encrusting communities. Ecology 62 : 830-847

Breen, P. A., Mann, K. H. (1976). Destructive grazing of kelp by sea urchins in eastern Canada. J. Fish. Res. Bd Can. 33 $1278-1283$

Brown, R. A., Seed, R. (1977). Modiolus modiolus (L.). An autoecological study. In: Keegan, B. K., Cleidigh, P. O., Boodin, P. J. S. (eds.) Biology of benthic organisms. Pergamon Press, Oxford, p. 93-100

Chess, J. R. (1978). Some procedures for assessing organisms associated with rocky substrata. In: Lipovsky, S. J., Simenstad, C. A. (ed.) Gutshop '78 Fish Food habits studies. Proceedings of the Second Pacific Northwest Tech. workshop. Washington Sea Grant Publication, Seattle, p. 25-28

Choat, J. H., Schield, D. R. (1982). Patterns of distribution and abundance of large brown algae and invertebrates herbivores in subtidal regions of northern New Zealand. $\mathrm{J}$. exp. mar. Biol. Ecol. 60: 129-162

Connell, J. H. (1972). Community interactions on marine intertidal shores. Ann. Rev. Ecol. Syst. 3: 169-192

Dayton, P. K. (1985a). The structure and regulation of some South American kelp communities. Ecol. Monogr. 55: $447-468$

Dayton, P. K. (1985b). Ecology of kelp communities. Ann. Rev. Ecol. Syst. 16: 215-245

Duggins, D. O. (1980). Kelp beds and sea otters: an experimental approach. Ecology 61: 447-453

Elliott, J. M. (1977). Some methods tor the statistical analysis of samples of benthic invertebrates, 2 nd edn. Freshwater Biological Association, Scientific Publication 25

Garwood, P. E., Vadas, R. L., Ojeda, F. P. (1.985). Competitive interactions among crustose coralline algae. In. Abstracts 24th Northeast Algal Symposium, Woods Hole, Mass., p. 12

Hagen, N. T. (1983). Destructive grazing of kelp beds by sea urchins in Vestfjorden, northern Norway. Sarsia 68: $177-190$

Harris, L. G. (1986). Size-selective predation in a sea anemone, nudibranch, and fish food chain. The Veliger 29 $38-4.7$

Harris, L. G., Witman, J. D., Rowley, R. (1984). A comparison of sea urrimn recruitment at sites on the Atlantic and Pacific coasts of North America. In: Keegan, B. K., O Connor, B. D. S. (eds.) Proceedings of the Fifth International
Echinoderm Conference. Galway, Ireland, A. A. Balkema, Boston, p. 389

Harrold, C., Reed, D. C. (1985). Food availability, sea urchin grazing and kelp forest community structure. Ecology 66: $1160-1169$

Himmelman, J. H. (1986). Population biology of green sea urchins on rocky barrens. Mar. Ecol. Prog. Ser. 33: 295-306

Himmelman, J. H., Cardinas, A., Bouget, E. (1983). Community development following removal of urchins Strongylocentrotus droebachiensis from rocky subtidal zone of the St. Lawrence estuary, eastern Canada, Oecologia (Berl.) 59: $27-39$

Himmelman, J. H., Steele, D. H. (1971). Foods and predators of the green sea urchin Strongylocentrotus droebachiensis in Newfoundland waters. Mar. Biol. 9: 315-322

Johnson, C. R., Mann, K. H. (1982). Adaptations of Strongylocentrotus droebachiensis for survival on barren grounds in Nova Scotia. In: Lawrence, J. M. (ed.) International Echinoderms Conference, Tampa Bay. Balkema, Rotterdam, p. 277-283

Johnson, C. R., Mann, K. H. (1986a). The crustose coralline alga, Phymatolithon Foslie, inhibits the overgrowth of seaweeds without relaying on herbivores. J. exp. mar. Biol Ecol. 96: 127-146

Johnson, C. R., Mann, K. H. (1986b). The importance of plant defence abilities to the structure of subtidal seaweed communities: the kelp Laminaria longicruris de la Pylaie survives grazing by the snail. Lacuna vincta (Montagu) at high population densities. J. exp. mar. Biol. Ecol. 97 231-267

Keats, D. W., South, G. R., Steele, D. H. (1984). The ecology of juvenile green sea urchins (Strongylocentrotus droebachiensis) at an urchin dominated sublittoral site in eastern Newfoundland. In: Keegan, B. K., O'Connor, B. D. S. (eds.) Proceedings of the Fifth International Echinoderm Conference, Galway, Ireland. A. A. Balkema, Boston, p. 295-302

Keats, D. W., Steele, D. H., South, G. R. (1986). Atlantic wolfish (Anarhichas lupus L.; Pisces: Anarhichidae) predation on green sea urchins (Strongylocentrotus droebachiensis (O. F. Mull.); Echinodermata: Echinoidea) in eastern Newfoundland. Can. J. Zool. 64: 1920-1.925

Larson, B. R., Vadas, R. L., Keser, M. (1980). Feeding and nutritional ecology of the sea urchin Strongylocentrotus droebachiensis in Maine, USA. Mar. Biol. 59: 49-62

Lawrence, J. M. (1975). On the relationships between marine plants and sea urchins. Oceanogr mar Biol. A. Rev. 13: 213-286

Logan, A., MacKay, A. A., Noble, J. P. A. (1983). Sublittoral hard substrates. In: Thomas, M. L. H. (ed.) Marine and coastal systems of the Quoddy region, New Brunswick. Canadian Special Publ. of Fish. Aquat. Sci. 64, p. 119-139

Logan, A., Page, F. H., Thomas, M. H. L. (1984). Depth zonation of epibenthos on sublittoral hard substrates off Deer Island, Bay of Fundy, Canada. Estuar. coast. Shelf Sci. 18: 571-592

Mann, K. H. (1972). Ecological energetics of the seaweed zone in a marine bay on the Atlantic coast of Canada. I. Zonation and biomass of seaweeds. Mar Biol. 12: 1-10

Mann, K. H. (1977). Destruction of kelp-beds by sea urchins: a cyclical phenomenon or irreversible degradation? Helgoländer wiss. Meeresunters. 30: 455-467

Miller, R. J. (1985). Succession in sea urchin and seaweed abundance in Nova Scotia, Canada. Mar. Biol. 84: 275-286

Miller, R. J., Colodey, A. G. (1983). Widespread mass mortalities of the green sea urchin in Nova Scotia, Canada. Mar. Biol. 73: 263-267 
Miller, R. J., Mann, K. M. (1973). Ecological energetics of the seaweed zone in a marine bay on the Atlantic coast of Canada. III. Energy transformations by sea urchins. Mar. Biol. 18: 99-114

Moreno, C. A., Sutherland, J. P. (1982). Physical and biological processes in a Macrocystis pyrifera community near Valdivia, Chile. Oecologia (Berl.) 55: 1-6

Noble, J. P. A., Logan, A., Webb, G. R. (1976). The recent Terebratulina community in the rocky subtidal zone of the Bay of Fundy, Canada. Lethaia 9: 1-17

North, W J. (1971). Introduction and background. In: North, W. J. (ed.) The biology of giant kelp beds (Macrocystis) in California. Nova Hedwigia 32: 1-96

Ojeda, F. P. (1987). Rocky subtidal community structure in the Gulf of Maine: the role of mobile predators. Ph. D. dissertation, University of Maine, Orono

Ojeda, F. P., Santelices, B. (1984). Invertebrate communities in holdfasts of the kelp Macrocystis pyrifera from southern Chile. Mar. Ecol. Prog. Ser. 16: 65-73

Osman, R. W. (1977), The establishment and development of a marine epifaunal community. Ecol. Monogr. 47: 37-63

Paine, R. T., Vadas, R. L. (1969). The effects of grazing by sea urchins, Strongylocentrotus spp., on benthic algal populations. Limnol. Oceanogr 14: 710-719

Patterson, M. R. (1984). Patterns of whole colony prey capture in the octocoral, Alcyonium siderium. Biol. Bull. mar biol. Lab., Woods Hole 167: 613-629

Pringle, J. D. (1984). Efficiency estimates for various quadrat sizes used in benthic sampling. Can. J. Fish. Aquat. Sci. 41 1485-1489

Pringle, J. D. (1986). A review of urchin-algal associations with a new synthesis for nearshore, eastern Canadian waters. Monografias Biologicas 4: 191-218

Pringle, J. D., Sharp, G. J., Caddy, J. F. (1980). Proceedings of the workshop on the relationship between sea-urchin grazing and commercial plant/animal harvesting. Can. Tech. Rep. Fish. Aquat. Sci. 954

Santelices, B., Ojeda, F. P. (1984). Population dynamics of coastal forests of Macrocystis pyrifera in Puerto Toro, Isla Navarino, Southern Chile. Mar Ecol. Prog. Ser. 14: $175-183$

SAS Institute (1986). SAS user's guide: statistics. SAS Institute Inc., Cary, North Carolina

Scheibling, R. E. (1986). Increased macroalgal abundance following mass mortalities of sea urchins (Strongylocen-

This article was presented by Dr J. Winter, Valdivia, Chile trotus droebachiensis) along the Atlantic coast of Nova Scotia. Oecologia (Berl.) 68: 186-198

Scheibling, R. E., Stephenson, R. C. (1984). Mass mortality of Strongylocentrotus droebachiensis (Echinoderm: Echinoidea) off Nova Scotia, Canada. Mar. Biol. 78: 153-164

Sebens, K. P. (1982). Competition for space: growth rate, reproduction, and escape in size. Am. Nat. 120: 189-197

Sebens, K. P. (1985). The ecology of the rocky subtidal zone. Am. Scient. 73: 548-557

Sebens, K. P. (1986a). Community ecology of vertical walls in the Gulf of Maine, U.S.A.: small-scale processes and alternative community states. In: Moore, P. G., Seed, R. (eds.) The ecology of rocky coasts. Columbia Univ. Press, New York, p. 346-371

Sebens, K. P. (1986b). Spatial relationships among encrusting marine organisms in the New England subtidal zone. Ecol. Monogr. 56: 73-96

Sokal, R. R., Rohlf, F. J. (1981). Biometry, 2nd edn. W H. Freeman, San Francisco

Steneck, R. S. (1978). Factors influencing the distribution of crustose coralline algae (Rhodophyta: Corallinaceae) in the Damariscotta River estuary, Maine. M.S. thesis, University of Maine, Orono

Steneck, R. S. (1982). A limpet-coralline alga association: adaptations and defenses between a selective herbivore and its prey. Ecology 63: 507-522

Steneck, R. S. (1986). The ecology of coralline algal crusts: convergent patterns and adaptative strategies. Ann. Rev. Ecol. Syst. 17: 273-303

Suchaneck, T H. (1986). Mussels and their role in structuring rocky shore communities. In: Moore, P. G., Seed, R. (eds.) The ecology of rocky coasts. Columbia Univ. Press, New York, p. $70-96$

Wainwright, S. A., Koehl, M. A. R. (1976). The nature of flow and the reaction of benthic cnidaria to it. In: Mackie, G. O. (ed.) Coelenterate ecology and behavior. Plenum Press, New York, p. 5-21

Wharton, W G., Mann, K. H. (1981). Relationship between destructive grazing by the sea urchin Strongylocentrotus droebachiensis and the abundance of american lobster, Homarus americanus on the Atlantic coast of Nova Scotia. Can. J. Fish. Aquat. Sci. 38: 1339-1349

Witman, J. D. (1985). Refuges, biological disturbance, and rocky subtidal community structure in New England, Ecol. Monogr 55: 421-455

Manuscript first received: November 5, 1988

Revised version accepted: June 9, 1989 